Indonesian Journal of EFL and Linguistics

Vol. 1 No. 1, 2016

eISSN: 2503-4197, pISSN: 2527-5070

www. indonesian-efl-journal.org

DOI: http://dx.doi.org/10.21462/ijefll.v1i1.6

\title{
The Implementation of British Parliamentary Debating in Mulawarman Debate Society (MDS)
}

\author{
Lely Agustina \\ IAIN Samarinda, Indonesia \\ Bahrani \\ IAIN Samarinda, Indonesia \\ Email: bahranibadri69@gmail.com
}

\begin{abstract}
:
In English debate, the students will be exposed to the real problems facing a society or a nation. The students are required to be able to give a strong and reasonable statement and solution so that they can practice English and convince the public that their idea will be expressed freely. This study found that there were some differences related to the implementation of British Parliamentary debating system, such us the differences of the amount of debater and adjudicator and length of speech. Those differences actually did not give bad effect significantly during the observation because of during observations, each member acted his or her role as well as the regulation of British Parliamentary debating system. It can be said that they had fulfilled their role fulfillment as debater, time keeper or the speaker and as adjudicator in every single debating practice. Beside the differences mentioned above, everything related to the implementation of British Parliamentary debating system in Mulawarman Debating Society were the same as the standard regulation of the British Parliamentary Debating System. For instance, there was case building for fifteen minutes before debating, the debater delivered POI, both accepted and declined it, and in the debate practice of MDS, the adjudication was also done by the adjudicator through giving verbal adjudication and ranking the team. The motion was also given by the adjudicator in the debate practice of MDS.
\end{abstract}

Keywords: British Parliamentary Debating, English debate, MDS 


\section{INTRODUCTION}

The level of competition of human resources at the national and international job market is increasing. The increasing of the use of science and new technologies in various fields of business is undeniable, as well as the increasing of the level of professionalism needs (knowledge, hard skills, soft skills). Nowadays, most science and technology programmes are in English. Knowledge of hard skills, soft skills, economy, business are also written in English. Since the use of science and technology are increasing in the bussiness and job-seeking competition, the needs of mastering English language is also increasing undeniably. In order to survive and be more competitive, we need to master English. As we know, English language is used internationally and it is the world's most widely studied foreign language (Richard and Rodgers, 1986).

People nowadays do various learning ways to master the English. For university students, one of the ways to increase the English proficiency is through English debating. The Ministry of Education and Culture has formulated policies in order to produce smart, comprehensive and competitive men. The Ministry of Education and Culture of Indonesia believe that one of the coaching businesses to make it happen is through debate competition, which has been formulated in the National University Debating Championship (NUDC).

There are many different styles of debating system around the world. Some of the styles that are used are Australian, US Parliamentary, even the Dutch do it differently, but the one that the researcher concerns here is British Parliamentary Debating System. This is the standard form used at university level. It differs radically from the schools style to which some young debaters are used (Rydian, 2014).

The British Parliamentary Debating is chosen as the official international debate system because British Parliamentary Debating system offers some advantages. The advantages of British Parliamentary Debating are not limited to the connections you immediately make to debaters around the world. British Parliamentary Debating offers debaters the opportunity to engage a variety of controversial issues. With ample opportunities for debaters to interact through the use of "points of information", the format is particularly appealing to audiences. Perhaps the most unique characteristic of the British Parliamentary Debating format is that the grouping which features four teams, two on the "proposition" and two on the "opposition". Each of these teams is independent of the others, prepares separately and is ranked from first to fourth at the end of the round.

English debat encourages the students' creativity to explore the language, since they are asked to develop their arguments from certain motions. By practicing speaking in the debate practice, they improved their fluency as well as their confidence (Fauzan, 2016). English debate activities require students not only to be able to express their ideas in English, but also requires students to be able to master the global knowledge and issues, to analyze, to make judgments, and to convince the public. In the debate, students will be exposed to the real problems facing a society 
or a nation. Students are required to be able to give a very strong and reasonable statement and provide the solution so that they can convince the public that their idea is a lot better than the others. Therefore, English debate will automatically improve not only the students' speaking ability, but also the knowledge and critical thinking of them.

As regards communication skills in general, students' own perceptions seem to indicate that taking part in debate activity does provide a boost. Evidence from United State of America college students participating in classroom debate in various subjects has highlighted that the activity improved their communication skills, with $74 \%$ of students from six university classes agreeing to this. Furthermore, an improvement in communication and speaking skills was perceived as the most important benefit of competitive debate in surveys of 286 university and 193 high school students in the US (William and Worth, 2004).

According to the London Debate Challenge, participating in competitive debate helped to develop students' skills in selecting evidence and structuring and summing up an argument, with potential 'knock-on' benefits for their written work, as well as developing their speaking and listening skills (Jerome and Algarra, 2005). In addition, university students in Japan, responding to a survey of competitive debaters, listed improved English as a benefit of their participation. There were 109 participants in parliamentary debate, $56.9 \%$ felt that debating improved their English, while $46.6 \%$ of 58 participants in National Debate Tournament-style parliamentary debate identified this as a benefit (Inoue and Nakano, 2004).

\section{REVIEW OF RELATED LITERATURE}

\subsection{Debate}

A debate is a speaking situation in which opposite points of view are presented and argued (Dale and Wolf, 2000). A debate is about the real or simulated issue. The learners' roles ensure that they have adequate shared knowledge about the issue and different opinions or interest to defend. At the end of activity, they may have to reach a concrete decision or put the issue to a vote (Littlewood, 1981). Debate is data in which people take up positions, persue arguments and expound on their opinions on a range or matters; with or without some sort of lead figure or chair person (Carter and Mc Carthy, 1997).

Debate is one of effective speaking activity which encourages students to improve their communication skill. Debates are most appropriate for intermediate and advanced learners who have been guided in how to prepare for them $\left(\mathrm{O}^{\prime}\right.$ 'Mallay and Pierce, 1986).

\subsection{British Parliamentary Debate}

British Parliamentary debating system is a common form of academic debate. It has gained support in the United Kingdom, Ireland, Canada, India, Europe, Africa, Philippines and United States, and has also been adopted as the official style of the World Universities Debating Championship and European Universities Debating Championship. In British Parliamentary debating system, there are 4 teams in each 
round. Two teams represent the Government, and two teams represent the Opposition. The Government supports the resolution (motion), and the Opposition opposes the resolution. The teams are also divided into the Opening and Closing halves of the debate (Husnawadi \& Syamsudarni, 2016).

In the debate technical system, we will get some items which relate to the debate process. The following are some items related to British Parliamentary Debate :

\subsubsection{Motion}

A motion, also known as a proposition or resolution in other formats, is a statement that usually sets the topic for the given debate. Usually, this is an unambiguously worded statement that is general in terminology in order to be understood by not only the debaters themselves but also by the general audience.

There are three types of motions in any parliamentary debate, depending on how specific or broadly defined it is. These are known as open, semiclosed and closed motions. he terms are always defined by the Prime Minister. In any debate, the motion is always supported by the government and opposed by the opposition, regardless of how the motion is worded. An open motion is a motion or resolution that is broad and can be defined quite liberally. A semi-closed motion, like an open motion, is also broad in scope. However, the context for which the motion is set is more limited than in an open motion. A closed motion, unlike the previous two types of motions, is a motion that is usually specific in scope while still leaving room for interpretation.

\subsubsection{Definition}

For debating to proceed, both teams need a clear understanding of what the motion means. This requires the motion to be defined so that everyone (debaters, adjudicators, and audiences) knows what is being debated. Problem arise if the two teams present different understandings of the meaning of the motion.

The definition given by Prime Minister should state the issue(s) for debate arising from the motion, stating the meaning of any terms in the motion which require interpretation. The definition must :

1) have a clear and logical link to the motion - this means that an average reasonable person would accept the link made by the member between the motion and the definition (where there is no such link the definition is sometimes referred to as a "squirrel");

2) not be self-proving - a definition is self-proving when the case is that something should or should not be done and there is no reasonable rebuttal. A definition is may also be self-proving when the case is that a certain state of affairs exists or does not exist and there is no reasonable rebuttal (these definitions are sometimes referred to as "truisms").

3) not be time set - this means that the debate must take place in the present and that the definition cannot set the debate in the past or the future.

4) not be place set unfairly - this means that the definition cannot restrict the debate so narrowly to a particular geographical or political location that a 
participant of the tournament could not reasonably be expected to have knowledge of the place (Flynn, 2014).

\subsubsection{Case Building}

Case building is when the teams have fifteen minutes after the announcement of the motion by the Adjudicator to prepare their speeches before the start of the debate. In the case building, the teams are permitted to use printed or written material during preparation and during the debate. Printed material includes books, journals, newspapers and other similar materials. The use of electronic equipment is prohibited during preparation and in the debate. Especially for the first speaker of the first government, Prime Minister should be aware to the motion, to set up the debate.

\subsubsection{Theme Line}

Theme line is the underlying reason which answers the big question "why" one side of the house supports or opposes a motion. Theme line is what a team needs to proof, it is also the main reason why a team attacks the opponent's case.

\subsubsection{Argument}

A debate is like a battle of argument, in which each team stands on their position, attacks the opposite and defends their own case. The praiseworthy jobs can be done well by using critical and logical thinking. Argument is the fragment of thought to support the theme line (Rohmatika \& Ro'is, 2014).

\subsubsection{Rebuttal}

In order to win a debate, debaters not only need to build a strong case but they also have to attack their opponent's arguments and provide strong defense from any attacks. That is why, rebuttal is one of the key to get the crown of victory. Basically, there are two kinds of rebuttal. Global rebuttal, it is an attack against the main core of the opponent's case, the theme line. Consequently, their case is crumbling down. Detailed rebuttal, it is an attack towards each argument or example (Rubiati, 2010).

\subsubsection{Point of Information (POI)}

Points of Information is a question directed to the member speaking, may be asked between first minute mark and the six-minute mark of the members' speeches (speeches are of seven minutes duration). To ask a Point of Information, a debater should stand, place one hand on his or her head and extend the other towards the debater of speaking. The member may announce that they would like to ask a "Point of Information" or use other words to this effect and should not exceed fifteen seconds in length. The debater who is speaking may accept or decline to answer the Point of Information.

\subsection{The Procedure of British Parliamentary Debate}

\subsubsection{Prime Minister}

The debate begins with a seven-minute speech by the Prime Minister. The Prime Minister has two basic responsibilities: to define and interpret the motion and to 
develop the case for the proposition. Defining and interpreting the motion are related although subtly different processes. When defining the motion, the Prime Minister will explicitly define any ambiguous terms that might be contained in the motion. When interpreting the motion, the Prime Minister will then use those definitions along with the motion as a whole to focus and narrow the motion so that the rest of the debate can be productive.

The second responsibility of the Prime Minister is to construct a case for the proposition. Simply stated, a "case" consists of one or more arguments supporting the Prime Minister's interpretation of the motion. Therefore, the Prime Minister will outline the arguments supporting the interpretation and begin to develop each of those arguments. The Prime Minister need not present all of the arguments for the First Government team. In many cases, the Prime Minister will state that the First Government team will have a certain number of arguments, that some will be presented in this speech and others by the Deputy Prime Minister.

\subsubsection{Leader of the Opposition}

The Leader of the Opposition should explicitly accept the definition and interpretation of the motion as presented by the Prime Minister. In extraordinary cases, when the definition is completely unreasonable as to preclude meaningful debate, the Leader of the Opposition has the right to reject the definition. The Leader of the Opposition has two primary responsibilities. First, the Leader of the Opposition should refute part or all of the Prime Minister's arguments for the motion. Because of the limits of time, the Leader of Opposition cannot reasonably expect to refute all of the Prime Minister's arguments. The proper goal is to select and refute the most important arguments presented by the Prime Minister. Second, the Leader of the Opposition should present one, two, or three arguments directed against the Prime Minister's interpretation of the motion. These arguments are different from those arguments offered in refutation. They should consist of the most persuasive reasons that the Leader of the Opposition can present to convince the audience to reject the motion as interpreted by the Prime Minister.

\subsubsection{Deputy Prime Minister}

The Deputy Prime Minister has three primary obligations: to refute arguments presented by the Leader of the Opposition, to defend the case presented by the Prime Minister, and to add one or more arguments to the case presented by the Prime Minister. First, the Deputy Prime Minister defends the case presented by the Prime Minister by engaging any refutation presented against the case by the Leader of the Opposition. This task needs to be accomplished in a very systematic fashion. The Deputy should take up the Prime Minister's argument one by one and defend each argument against any refutation by the Leader of the Opposition. Second, the Deputy Prime Minister should refute any of the independent arguments presented by the Leader of the Opposition. Like the Leader of Opposition, the Deputy should not try to refute all arguments, just the most important ones. Finally, the Deputy Prime Minster should add one or two arguments to the case presented by the Prime Minister. The reasons for adding new arguments in this speech are two-fold: First, 
the Prime Minister may not have had adequate time to develop all of the arguments that the First Government team wishes to present and second, presenting these additional arguments gives the judges and audience a way to judge the ability of the Deputy Prime Minister with respect to his or her ability to construct arguments.

\subsubsection{Deputy Leader of Opposition}

The duties of the Deputy Leader of the Opposition are similar to those of the Deputy Prime Minister. First, the Deputy Leader should advance the refutation offered by the Leader of the Opposition. The Deputy Prime Minister will have engaged the refutation presented by the Leader of Opposition. At this time, the Deputy Leader needs to advance that refutation by showing that the original refutation is still sound. Second, the Deputy Leader should defend the arguments presented by the Leader of the Opposition. The task of the Deputy Leader is to make sure that these arguments still stand firm in the mind of the judges and audience. To do so, the Deputy leader needs to consider each argument one by one, engage any refutation offered by the Deputy Prime Minister, and therefore rebuild each argument. Third, the Deputy Leader should present one or more new arguments against the proposition. These arguments can be similar to those arguments raised by the Leader of the Opposition, yet they should be new ones to give the judges and audience the ability to judge the Deputy Leader's argument construction skills.

\subsubsection{Member of Government}

The Member of Government needs to defend the general direction taken by the First Government team and needs to show how the Second Government team has a new and fresh position or somehow is adding something new and dynamic to the debate. The first responsibility of the Member of the Government is to defend the general direction of the debate initiated by the First Government team. In so doing, the Member of Government demonstrates a sense of loyalty to the other debaters defending the motion. This part of the Member's speech is important but need not be time consuming. Second, the Member of Government should continue refuting arguments made by the First Opposition team. The Member of Government should not use the same refutation as provided by debaters of the First Government team, but should introduce new points of refutation unique to the Second Government team. Finally, the Member of Government should develop one or more arguments that are different from but consistent with the arguments offered by the First Government team. These new arguments - referred to as an "extension." The extension is one of the most important tasks of the Member of Government's speech as it provides an opportunity to distinguish the Second Government team from the First Government while simultaneously remaining consistent with the overall approach of the First Government.

\subsubsection{Member of Opposition}

Like the Second Government team, the goal of the Second Opposition team is to remain consistent with the First Opposition team while presenting a perspective unique to the Second Opposition. To accomplish this goal, the Member of Opposition needs to fulfill several roles. First, the Member of Opposition should 
defend the general perspective taken by the First Opposition team. This need not be a time-consuming enterprise, but its accomplishment shows how the Member of Opposition is being loyal to the arguments of the First Opposition team. Second, the Member of Opposition should briefly continue the refutation of the case presented by the First Government team. Again, this continued refutation should be brief and should involve new points of refutation not yet considered by members of the First Opposition team. Third, the Member of Opposition should present more specific refutation of the arguments introduced by the Member of Government. Refutation of the Member of Government's arguments is an important task because these are completely new arguments supporting the government side and have not yet been joined by the opposition side. Finally, the Member of Opposition should present an extension - an argument consistent with, yet different from that presented by the First Opposition team. Like the Government's extension, presenting the Opposition's extension is an important responsibility of the Member of Opposition because it allows the Second Opposition team to show its loyalty to the First Opposition team while clearly differentiating themselves form the First Opposition.

\subsubsection{Government Whip}

The whip speakers for both teams have the responsibility to close the debate for their respective sides. The Government Whip should accomplish three goals. The first responsibility of the Government Whip is to refute the extension offered by the Member of Opposition. This extension has yet to be discussed by the Government team and therefore its refutation is an important responsibility of the Government Whip. Second, the Government Whip should defend the extension offered by the Member of Government. The Member of Government's extension is a very important part of the Second Government's case and in all likelihood has been refuted by the Member of Opposition. Therefore, defending this extension is an important responsibility of the Government Whip. The final and the most important responsibility of the Government Whip is to summarize the debate from the perspective of the Government side. The summary may be accomplished in a number of ways. The summary can examine the issue as addressed by both teams; it can regroup the issues into categories that are new to the debate; it can discuss the debate from a different or higher perspective than has been previously introduced. The summary should be fair to the First Government team but should focus on the arguments pursued by the Second Government team.

\subsubsection{Opposition Whip}

The responsibilities of the Opposition Whip are almost identical to those of the Government The Opposition Whip should refute the extension offered by the Member of Government, defend the extension offered by the Member of Opposition, and summarize the debate from the perspective of the Opposition side. The details of this speech are exactly like those of the previous speech except that they focus on the Opposition side of the debate rather than the Government side. Once again, the primary goal of this speech is to summarize the debate from the perspective of the Opposition side, particularly from the point of view of the Second Opposition team. 
This summary should fairly support the Opposition side of the debate while focusing on the accomplishments of the Second Opposition team.

\section{RESEARCH METHODOLOGY}

Descriptive method is a method in researching the status of a group of people, an object, a set of conditions, a system ideas or a class of events in the present (Fauzan: 2008). The purpose of this descriptive study is to make a description, picture, or a painting in a systematic, factual and accurate information on the facts, natures and the relationship between the phenomena under investigation.

The researcher used descriptive research design to describe the implementation of British Parliamentary Debating System in Mulawarman Debating Society (MDS). Since the researcher wanted to know and describe the implementation of British Parliamentary debating system in Mulawarman Debating Society (MDS), the subjects in this study were the active members of Mulawarman Debating Society (MDS). The total of active members were twelve (12) members.

In qualitative research, the researcher collected and analyzed data simultaneously to draw a temporary conclusion and repeated the cycles several times, deciding what data needed to be collected again to verify their temporary conclusion. Therefore, the researcher had to be involved himself in the process of data collection using all kinds of necessary instruments. The instruments used by the researchers are called human instruments (Latief, 2012).

Research instruments of this research were interview guide, observation sheet, field note and a digital camera. Interview guide was used by the researcher in the interview. It contained important questions which was used to find the important information and data for this research. Obervation sheet was used when the researcher did the observation to find the important information and data for this research. Field note was taken by the researcher since the first time the researcher arrived at the location of first and second observation. Field note was used to describe the condition and the situation of the school as clear as possible and the camera digital was used to record the result of interview and the observations.

In order to collect the data that were needed in this study, the researcher used the techniques: interview, observation, and documentation. The interview is a research conducted by two parties, namely the interviewer who asks the question and the interviewees who is asked questions that provide answers to questions with a purpose. By interviewing, it provides the researcher a means to gain a deeper understanding of how the participant interpret a situation of phenomenon than can be gained through observation (Moleong, 2010). Interview is conducted transparantly by the researcher to the President of Mulawarman Debate Society (MDS) as informant. She asked about the implementing of British Parliamentary Debate style as the common style they use in debating. In this study, the researcher observed the subject's real debating practice that use British Parliamentary debating system by attending the practicing debate process in the location. The researcher used observation sheet to get the data based on the reality. The reseacher attended two meetings of the practicing debate. Every each meeting, the researcher observed 
the subjects and filled in the observation sheet. The researcher collected the documents which was considered as data such as document of Mulawarman Debating Samarinda (MDS) profile, letters, archival photographs, and journal activities.

Data analysis techniques are important parts in a research because without analysis the researcher cannot take a decision of this research. According to Bogdan in Metode Penelitian Kuantitatif Kualitatif dan $R \& D$, data analysis is the process of systematically searching and arranging the interview transcripts, fieldnotes, and other materials that you accumulate to increase your own understanding of the to enable you present what you have discovered to others (Sugiyono, 2012).

Data analysis has been developed when researcher entering in field. Qualitative data analysis during field based model of Miles Huberman consists of three activities, namely the data reduction, the data display and conclusion drawing/verification. Data Reduction. Sugiyono argued that "data reduction means summarize, choosing subject matter, focus on the important things, sought themes and patterns and discard unnecessary ". In the study, the data obtained by the researcher from the field should be recorded and investigated in detail. The longer the researcher in the field then the more data is obtained. For that reason, data analysis through data reduction is required. Thus, the data reduced will give a clear description of the problem under study.

Data Display. After the data was reduced, then the next step is to display the data. In qualitative research, data presentation in the form of brief descriptions, chart, relationships between categories, flowchart and etc. In this study, the researcher displayed the data in the form of a brief description to make it easier to understand the phenomena that occur in the field. By displaying the data, it would be easier to understand what occurred, subsequent work plan based on what has been understood previously.

Conclusion Drawing / Verification. Conclusions in qualitative research will answer the problem of study formulated from the beginning, but maybe not, because of the problem and formulation issues in qualitative research is still tentative and will develop after research in the field. The third step is intended to look for the meaning of the data collected. To reach a proper conclusion then the conclusion is verified during the research process in order to obtain an accurate conclusion. Thus, the process of data processing and analysis should be performed using the data processing steps accordingly. Through these stages is expected that the data obtained from research can produce results in accordance with the purpose of research.

\section{FINDINS OF THE RESEARCH}

The data which have been obtained from the field are reported based on the interview to the President of Mulawarman Debating Society on July $3^{\text {rd }} 2014$, the two observation on September $15^{\text {th }}$ and $24^{\text {th }}, 2014$ and the document analysis. The important findings were found by the researcher which is related to her research, "The Implementation of British Parliamentary Debating System in Mulawarman Debating Society" are described into some points. 
Based on the interview and the observations, the researcher found that both first and second observation, the members prepared the condition to debate, the President of Mulawarman Debating Society (MDS) divided the members into the team which every team consist of two debaters. As she said in the interview,

"Before we practicing debate, I sometimes divide the members into four teams which every team consist of two debaters, if the member who attend are eight or nine."

It's proven in the first observation. Even though the Opening Opposition team consist of one debater, Dara Silfiana, but she acted double role as Leader of Opposition and Deputy Leader of Opposition.

The amount of Mulawarman Debating Society (MDS) members when practicing debate were different from the procedure of British Parliamentary Debating system due to the lack of members who attended the debating practice. As the answer of the Mulawarman Debating Society (MDS) President in the interview,

"Even though not all the members can attend the debating practice, only three to nine members who can attend, so to fulfill the total of debater, some members sometimes act double role, or even we just practice to the opening section only if the debate is lack of the members."

In the first observation, there were nine members who attended the debate practice, seven members acted as the debaters, one member acted as adjudicator and one member acted as the speaker who also acted as the time keeper. Meanwhile, on the second observation, only three who attended the debating practice, two acted as the debater and one acted as the adjudicator who also acted as the speaker and the time keeper.

The findings about the case building in the debating practice showed that both first and second observation, the debaters had case building before debate for fifteen minutes. Each team included the debaters had discussion about the motion and made notes on their book.

The researcher found that each debater has already known about the roles of debaters. As the President of Mulawarman Debating Society statements,

"The process of debating practice that uses British Parliamentary is by doing their role fulfilment optimally. Even though not all the members can attend the debating practice, only three to nine members who can attend, so to fulfill the total of debaters, some members sometimes act double role, or even we just practice to the opening section only if the debate is lack of the members. But the most importantly is that the members must know their role and the responsibilities in the debate, both as the debater, the speaker, the time keeper or as the adjudicator. When practicing, each member acts as, the opening team, there are Prime Minister, Leader of Opposition (LO), Deputy Prime Minister (DPM), Deputy Leader of 
Opposition (DLO), and for the closing team, there are Member of Government (MG), Member of Opposition (MO), Government Whip $(G W)$, and Opposition Whip $(O W)$. So, by having these different teams or roles, they also could finally gain their role fulfillment. So, each debater in every single debate practice always play their own role fulfilment, for example role as PM, LO, etc."

The statement of the President above was proven on the first and second observation. Each debater played his or her role fulfilment both on the first and second observation. On the first observation, researcher found that the seven debaters played his or her role fulfilment as Prime Minister, Deputy Prime Minister, Leader of Opposition, Deputy Leader of Opposition, Member of Government, Member of Opposition, Government Whip, and Opposition Whip. The researcher has provided the details of the role of each debater in the Observation Sheet I. Two others members who also acted as adjudicator played her role fulfilment to give the motion "This House Believe that Democratic Countries Should Establish School Exclusively for LGBTQIA (Lesbian, Gay, Bisexual, Transgender, Queer, Intersex, Ally" and she adjudicated the debaters by announcing the team rank and explaining the result of the adjudication orally, and the time keeper who also acted as the speaker played her roles fulfilment to open the debate and counted the time of debaters' speech. On the second observation, it was found that even the debate practice was lack of members to role as debaters, but the two debaters who acted double role, played her role fulfilment as Prime Minister - Deputy Prime Minister, and Leader of Opposition - Deputy Leader of Opposition. The researcher has also provided the details of the role fulfillment in the observation sheet II. Meanwhile, the adjudicator also fulfilled her roles by giving the motion "This House Regrets the Withdrawal of United State of America Troops from Iraq" and also acted as the speaker and the time keeper to count the time of debating.

Related to the Point of Information (POI), most of the debater delivered the Point of Information (POI) to the speaker (debater who is speaking). It is proven on the first observation, the debaters who asked the POI to the speaker during the debate were three debaters, and there were two debaters (double role) who delivered POI on the second observation. In asking POI, the debaters stood while saying "POI please" and place one hand on his or her head towards the debater of speaking. The others findings that interested to be described is about the speech length of each debater when they were speaking. Most of them took seven minutes to eight minutes when they were speaking both in first and second observation.

Based on the documentation, the researcher found some important data which can be additional data related to the implementation of British Parliamentary Debating system in Mulawarman Debating Society, such as some photographs of Mulawarman Debating Society programs that was Workshop of National University Debating Championship (NUDC), Samarinda Varsity Debating Championship (SVDC), and Short Intensive Debate Training with On That Point (OTP). 


\section{DISCUSSION}

Since the existence of British Parliamentary Debating system is getting famous in the world, it has been implementing in most universities in Indonesia. The system which also used as the system of World University Debating Championship (WUDC) interested some education experts especially in University to use the system as one of the system of debating championship at university level. This phenomena shows that to compete or face globalization era, the university is considered to responsible for developing hard skill and soft skill of the students.

Due to participating the English debate competition both national and international, Mulawarman Debating Society (MDS) as one of debating club in Mulawarman University does its responsibility by practicing debate using British Parliamentary Debating system.

In British Parliamentary Debating system, there are eight debaters, four adjudicators and one speaker in one time of debate practice. The debaters are divided into two teams: Government team which consists of Opening Government and Closing Government and Opposition team which consists of Opening Opposition and Closing Opposition. Each team has two debaters and eights debaters in total.

In Mulawarman Debating Society, when the members did the debate practice, they divided the members into teams. The dividing was done by the president of MDS. The adjudicators divided the members by following the standard regulation of the British parliamentary system. They divided the members into two teams: Government team which consists of Opening Government and Closing Government and Opposition team which consists of Opening Opposition and Closing Opposition. But there is one condition when the number of debaters are not enough to be divided to as the standard regulation of the British parliamentary system. In that situation the president still divides the members into the teams but the dividing is according to how many members are coming in the debate practice time.

Just like the researcher saw in the second observation, the debate that should be done by two teams, opening and closing, was done only by one team, it was only opening team. It happened because the members that came at the time were only three people. Therefore, the people were not enough to be divided into two teams which should contained eight people.

In British Parliamentary debate system, the Government team is divided into two groups, Opening Government and Closing Government. The opening government consists of two speakers: Prime Minister and Deputy Prime Minister. The closing government also consists of two speakers: Member of the Government and Government Whip. The total of the speakers in government team are four speakers

The same as the Government team, in British Parliamentary debate system, the opposition team is also divided into two groups, Opening Opposition and Closing Opposition. The opening opposition consists of two speakers: Leader of the Opposition and Deputy Leader of the Opposition. The closing opposition also 
consists of two speakers: Member of Opposition and Opposition Whip. The total of the speakers in the opposition teams are four speakers.

In the Mulawarman Debating Society, the President of MDS not only divided the members into two teams, Government team and Opposition team, but also did the placement of the speakers by using lottery system. The place and name of the speakers were taken from the standard regulation of the British Parliamentary system. The Government team was divided into two groups, Opening Government and Closing Government. The Opening Government consisted of two speakers: Prime Minister and Deputy Prime Minister. The Closing Government also consisted of two speakers: Member of the Government and Government Whip. The total of the speakers in Government team were four speakers.

The Opposition team were also divided into two groups, Opening Opposition and Closing Opposition. The Opening Opposition consisted of two speakers: Leader of the Opposition and Deputy Leader of the Opposition. The closing opposition also consisted of two speakers: Member of Opposition and Opposition Whip. The total of the speakers in the opposition teams should have been four speakers, but the members that came to the debate practice were less than needed. Therefore, to make it complete, one of the three speakers acted double role. She was Dara Silfiana who acted as Leader of Opposition and Deputy Leader of Opposition.

Related to the role, in British Parliamentary Debating System, each debater has their own role which is different one another. From the opening team, Prime Minister, $1^{\text {st }}$ speaker for $1^{\text {st }}$ Government Team, should define and interprets the motion and develop the case for that interpretation of the motion. Deputy Prime Minister, $2^{\text {nd }}$ speaker for $1^{\text {st }}$ Government Team, should rebut the arguments given by Leader of Opposition, defend the case presented by Prime Minister, and add new arguments. Leader of Opposition , $1^{\text {st }}$ speaker for $1^{\text {st }}$ Opposition Team, should rebut the case of offered by the Prime Minister and constructs one or more arguments against the motion as the Prime Minister interpreted it. The last from the opening team is Deputy Leader of Opposition, $2^{\text {nd }}$ speaker for $1^{\text {st }}$ Opposition Team. The roles are rebuting the arguments given by Deputy Prime Minister, defending the case presented by Leader of Opposition, and adding new arguments. Those are the roles of the opening team.

The closing team has Member of Government, $1^{\text {st }}$ speaker for $2^{\text {nd }}$ Government Team, the roles are defending the general direction and case of the 1st Government team, developing a new argument that is different from but consistent with the case of the $1^{\text {st }}$ Government (sometimes called an extension), and continuing rebuttal of $1^{\text {st }}$ Opposition team's arguments focusing on new arguments introduced by the Deputy Leader of the Opposition. Government Whip, $2^{\text {nd }}$ speaker for $2^{\text {nd }}$ Government Team has the roles to defends the case presented by Member of Government, rebutes the arguments of Member of Government, and summarizes the entire debate from the point of view of the Government, defending the general viewpoint of both proposition teams with a special eye toward the case of the $2^{\text {nd }}$ Government team. 
For the closing opposition team, there is Member of Opposition, $1^{\text {st }}$ speaker for $2^{\text {nd }}$ Government Team which has the role to rebut the arguments introduced by the Member of Government and present the new opposition argument (extension). There is also Opposition Whip, $2^{\text {nd }}$ speaker for $2^{\text {nd }}$ Opposition Team, which has the role to defend the case presented by Member of Oppositiom, to rebut the arguments of Government Whip, to summarize the entire debate from the point of view of the Opposition team, and to defend the general viewpoint of both Opposition teams with a special eye toward the case of the $2^{\text {nd }}$ Opposition team.

In Mulawarman Debating Society, generally each member who performed as debater has fulfilled the role as the British Parliamentary Debating system. Due to the fulfillment of each role, the member who practiced tried his or her best in defining the motion, delivering their arguments, rebutting the statement of the other team, providing some extensions, summarizing the debate from the beginning until the ending.

In British Parliamentary Debating System, each debater has seven minutes to deliver the speech. Usually, if the debater uses time more than seven minutes, it could decrease the point or score of the debater him or herself. Therefore, to make the debater easier, he or she may bring a stopwatch to count the time for him or herself or him or her partner. In MDS, most of the the debaters deliver their statement and their argument around seven to eight minutes

To make debating more challenging, in British Parliamentary Debating system, there is a regulation which is the debaters who are not performing can ask the debater who is performing. The question is about something related to the content that is being explained by the one who is performing, namely Point of Information (POI). POI can be asked by debater to the speaker only in the special time, from the first to sixth minute of speech and the speaker him-self may accept or decline the POI. Beside asking the question to the speaker, the debater who delivers the POI can also give an argument or more in order to make clear or rebut the speaker's argument directly by standing, raising one of his/her hand higher than his/her head while saying, "POI, please" to the speaker. In delivering POI, the debater must deliver it clearly and briefly. It should last no longer than fifteen seconds.

According to the regulation about POI above, it can be said that during observations, every member has already done the POI. They delivered the POI in the protected time and delivered it by standing while saying, "POI, please". Most of them delivered POI and there were three debaters on the first observation and two debaters (double role) on the second observation.

In British Parliamentary debating system, the adjudication of debating is really important. Therefore, there should be three adjudicators to do the adjudication. The adjudicators should give the motion, decide which team is better than the other team and why, give the rank to the four groups of debaters and deliver the reason why one of the groups chosen to be the first rank, second, third and fourth. In Mulawarman Debating Society, when they do the debating practice, there is always adjudication. Even though the adjudication is not always done by three adjudicators, 
but the adjudication is always done by one adjudicator. The adjudicator still adjudicate the debating by determining the rankings of the teams and provide a verbal adjudication to the debaters. The British Parliamentary Debating System also regulates that the debate is presided over by a speaker. Where the Speaker keeps time and calls debaters to the floor. When the member of MDS practice, the speaker is there to run and to control the debate practice.

\section{CONCLUSION AND SUGGESTIONS}

\subsection{Conclusion}

Based on the result of the research and the analyzing of the data in the previous chapters, a conclusion was drawn related to the implementation of British Parliamentary debating system in Mulawarman Debating Society. The conclusion was that there were some differences related to the implementation of British Parliamentary debating system, such us the differences of the amount of debater and adjudicator and length of speech. Those differences actually did not give bad effect significantly during the observation because of during observations, each member acted his or her role as well as the regulation of British Parliamentary debating system. It can be said that they had fulfilled their role fulfillment as debater, time keeper or the speaker and as adjudicator in every single debating practice.

Beside the differences mentioned above, everything related to the implementation of British Parliamentary debating system in Mulawarman Debating Society were the same as the standard regulation of the British Parliamentary Debating System. For instance, there was case building for fifteen minutes before debating, the debater delivered POI, both accepted and declined it, and in the debate practice of MDS, the adjudication was also done by the adjudicator through giving verbal adjudication and ranking the team. The motion was also given by the adjudicator in the debate practice of MDS.

\subsection{Suggestions}

In English learning and teaching at university level, the contribution of practicing debate is not only to train the students capable in public speaking but the most important is to train them think critically, suitable with one of IAIN Samarinda's Mission that is educate the students to think and behave critically and creatively, so they can face the globalization wisely.

As the research significances tell about, the researcher would like to give suggestions in order to make everything related to debating better. For Mulawarman Debating Society, both the President and the member, it is important for them to manage the time of the debating practice, so that the amount of debater in every single debate practice can be sufficient, since the British Parliamentary debating system needs eight debater, so it is better for them to manage the correct time once a month. It is also really good for MDS to do the regeneration and recruitment as many as possible, so that the lack of the member when doing a speaking practice will not happen again. 
For the government, especially for Department of Education of East Borneo to give more attention toward English education development for university student in debating in East Borneo especially in Samarinda. Since British Parliamentary debating system is used as one of style in National University Debating Championship and World University Debating Championship, the government should conduct any competition of English Debate to prepare competitive student in English Debate for the national scale or even the International scale.

Finally, the last suggestion given to all English learners to learn English by debating. One of the oway to practice the debate is joining English debating club or organization such as, Mulawarman Debating Society. The Mulawarman Debating Society is one of the English debating organization which regularly practices the debate using British Parliamentary debating system. Considering the advantages of practicing debate is not only improving English speaking skill, but also others skill, writing, reading, and listening skill. The researcher also believes that by practicing debate, the ability of thinking critically can be improved significantly as well as practicing debate with various motion, such as motion related to politic, law, education, health, social, and others motion which is worthy to be debated. Therefore, the more we practice debate with various motion, the more we can improve our English skills, not only speaking skill but also writing, reading, and listening skill, because in debating, we use all those skill to make debate runs well.

\section{REFERENCES}

Arikunto, Suharsimi. (1993). Prosedur Penelitian Suatu Pendekatan Praktek. Jakarta : PT. Rineka Cipta.

Bailey, Kenneth. (1982). Methods of Social Research. New York : Free Prees.

Bogdan, R. C., Biklen K. (1982). Qualitative Research for Education; An Introduction to Theory and Methods, Boston London: Allyn and Bacon.

Bellon, Joe. (2000). A Research-based Justification for Debate across the Curriculum, Atlanta, Georgio State University.

Carter, Ronald and Mc Carthy. (1997). Exploring Spoken English, UK: Cambridge University Press.

Dale, Paulette and James C Wolf. (2000). Speech Communication Made Simple, NY: Miami-Dade Community College, 2nd Ed.

Fauzan, Umar. (2008). Pedoman Penulisan Skripsi. Samarinda: Universitas Widya Gama Mahakam

Fauzan, Umar. (2016). Enhancing Speaking Ability of EFL Students through Debate and Peer Assessment, EFL JOURNAL, Vol. 1(1), 2016. DOI: http://dx.doi.org/10.21462/eflj.v1i1.8

Fulcher, Glenn. (2003). Testing Second Language Speaking, Britain: Pearson Education Limited 
Flynn, Colm. (2014). Debating Tutorial Handsout. World Debating Website. Archived from: https://debate.uvm.edu/dcpdf/bphandbook.pdf, 1 March 2014

Harris, David P. (1969). Testing English as a Second Language, Georgetown University

Harmer, Jeremy. (2002). The Practice of English Language Teaching, Pearson Education limited England

Hornby, A. S. (2000). Oxford Advanced Learners $\square$ Dictionary of Current English, NY : Oxford University Press

Husnawadi, H. \& Syamsudarni, S. (2016). The Role of English Debating Tournament in the Face of the ASEAN Economy Community (AEC). Dinamika Ilmu. Vol. 16 No 1, 2016

Inoue, N. and Nakano, M. (2004). The Benefits and Costs of Participating in Competitive Debate Activities: Differences Between Japanese and American College Students. Wake Forest University/International Society for the Study of Argumentation. Venice Argumentation Conference, June 27-30

Jerome, L. and Algarra, B. (2006). English-Speaking Union London Debate Challenge: 2005-06 Final Evaluation Report. Cambridge and Chelmsford: Anglia Ruskin University

Latief, M. A. (2012). Tanya Jawab Metode Penelitian Pembelajaran Bahasa. Malang : Universitas Negeri Malang Press.

Littlewood, William. (1981). Communicative Language Teaching, UK: Cambridge University Press.

Kementrian Pendidikan dan Kebudayaan. (2013). Pedoman National University Debating Championship (NUDC). Jakarta

Moleong, Lexy J. (2010). Metodologi Penelitian Kualitatif, (Bandung : PT. Remaja Rosda Karya

O' Malley, J. Michael and Pierce, Lorraine Valdez. (1996). Authentic Assessment for English Language Learners, Addison-Wesley Company Inc

Richard and Rodgers. (1986). Approaches and Methods in Language Teaching. United Kingdom : Cambridge University Press

Rohmatika, Arina \& Ro'is, Syamsuddin. (2014). Penggunaan AREL pada Penyampaian Argumen di Klub Debat Bahasa Inggris STKIP PGRI Ponorogo. Dinamika Ilmu, Vol 14 No 2, 2014.

Rubiati, Richa. (2010). Improving Students' Speaking Skill through Debate Technique, Semarang : IAIN Walisongo Semarang

Rydian, Morgan. (2014). British Parliamentary Debating. Archived from: https://debate.uvm.edu/dcpdf/Morgan_BP_Text.pdf, March 1, 2014 
Sugiyono. (2006). Metode Penelitian Kuantitatif, Kualitatif, dan R\&D, Bandung: Alfabeta.

Susan Stainback, William Stainback. (1988). Understanding and Conducting Qualitative Research, Dubuque Iowa: Kendall/ Hunt Publishing Company.

http://parliamentarydebate.blogspot.com/BritishParliamentaryDebate 